\title{
PERTUMBUHAN DAN HASIL SELADA (Lactuca sativa L.) DENGAN PEMBERIAN PUPUK KANDANG DAN ABU SEKAM PADI DI INCEPTISOL
}

\author{
Evelyn $^{1}$, Kanang Setyo Hindarto ${ }^{2 *}$, Entang Inoriah ${ }^{1}$ \\ ${ }^{1}$ Program Studi Agroekoteknologi, Fakultas Pertanian, Universitas Bengkulu \\ ${ }^{2}$ Program Studi Ilmu Tanah, Fakultas Pertanian, Universitas Bengkulu \\ * Corresponding Author : setyo_hindarto@yahoo.com
}

\begin{abstract}
[GROWTH AND LETTUCE YIELD (Lactuca sativa L.) BY GIVING MANURE AND RICE HUSK ASH IN INCEPTISOL]. Increasing market demand for lettuce (Lactuca sativa L.) makes the prospect of developing lettuce very promising. Bengkulu Province is dominated by inceptisol soil types which have low soil fertility, making it less optimal for lettuce growth. Giving organic matter can increase soil fertility through improving soil physical, chemical and biological properties so that it can support the growth of lettuce. This study aims to determine the dosage of manure, the dose of rice husk ash and the optimal dose interaction for lettuce growth and yield. This research was conducted from May 2018 to July 2018 in Medan Baru, Muara Bangkahulu Subdistrict, Bengkulu City. The research design used was a Completely Randomized Design (CRD) consisting of two factors and repeated 3 times. The first factor is the dosage of cow manure with three levels, namely: 0 tons/ha, 15 tons/ha, and 30 tons $/$ ha. The second factor is the dose of rice husk ash which consists of three levels, namely 0 tons/ha, 3 tons/ha, and 6 tons/ha. Data from the observations were analyzed statistically by Analysis of Variance (ANOVA) using the F test at the level of 5\%. To determine the dosage of manure, the dose of rice husk ash and the optimal combination of doses for growth and yield of lettuce used the Polynomial Orthogonal method. The results showed that there was no interaction between cow manure and rice husk ash on the growth and yield of lettuce. The effect of cow manure has not shown the optimum dose for growth and yield of lettuce. The addition of manure doses up to 30 tons/ha was able to increase the value of plant height, number of leaves, leaf area, and fresh weighted plant weight of $0.189,0.038,0.931$ and 0.104 respectively. Giving rice husk ash up to a dose of 6 tons/ha did not have a significant effect on all observed variables.
\end{abstract}

Keyword: lettuce, inceptisol, manure, rice husk ash

\begin{abstract}
ABSTRAK
Peningkatan pemintaan pasar akan selada (Lactuca sativa L.)membuat prospek pengembangan selada sangat menjanjikan. Provinsi Bengkulu didominasi oleh jenis tanah inceptisol yang memiliki kesuburan tanah rendah sehingga kurang optimal untuk pertumbuhan selada. Pemberian bahan organik dapat meningkatkan kesuburan tanah melalui perbaikan sifat fisik, kimia, dan biologi tanah sehingga mampu mendukung pertumbuhan selada. Penelitian ini bertujuan untuk menentukan dosis pupuk kandang, dosis abu sekam padi serta interaksi dosis yang optimal untuk pertumbuhan dan hasil selada. Penelitian ini dilaksanakan mulai bulan Mei 2018 sampai Juli 2018 di Medan Baru, Kecamatan Muara Bangkahulu, Kota Bengkulu. Rancangan penelitian yang digunakan adalah Rancangan Acak Lengkap (RAL) yang terdiri atas dua faktor dan diulang sebanyak 3 kali. Faktor pertama ialah dosis pupuk kandang sapi dengan tiga taraf yaitu : 0 ton/ha, 15 ton/ha, dan 30 ton/ha. Faktor kedua adalah dosis abu sekam padi yang terdiri dari tiga taraf yaitu 0 ton/ha, 3 ton/ha, dan 6 ton/ha. Data hasil pengamatan dianalisis secara statistik dengan Analisis Varians (ANAVA) menggunakan uji F pada taraf 5\%. Untuk menentukan dosis pupuk kandang, dosis abu sekam padi serta interaksi dosis yang optimal untuk pertumbuhan dan hasil selada digunakan metode Polinomial Orthogonal. Hasil penelitian menunjukkan bahwa tidak terdapat interaksi antara dosis pupuk kandang sapi dan abu sekam padi terhadap pertumbuhan dan hasil selada. Pengaruh pupuk kandang sapi belum menunjukkan dosis optimum bagi pertumbuhan dan hasil selada. Penambahan dosis pupuk kandang hingga 30 ton/ha mampu meningkatkan nilai tinggi tanaman, jumlah daun, luas daun, dan bobot berangkasan segar tanaman berturut-turut sebesar 0,189, 0,038, 0,931, dan 0,104 . Pemberian abu sekam padi hingga dosis 6 ton/ha tidak memberikan pengaruh yang nyata pada seluruh variabel yang diamati.
\end{abstract}

Kata kunci: selada, pupuk kandang, abu sekam, inceptisol 


\section{PENDAHULUAN}

Tanaman selada (Lactuca sativa L.) merupakan tanaman sub-tropis, namun mampu beradaptasi dengan baik pada iklim tropis. Di Indonesia selada dimanfaatkan sebagai salad, lalapan atau sayuran hijau yang banyak manfaatnya bagi kesehatan (Rukmana, 2007). Tanaman ini tumbuh baik pada tanah yang bertekstur ringan, meskipun demikian tanah jenis lain seperti lempung berdebu dan lempung berpasir banyak juga digunakan sebagai media tanam selada (Harianto et al., 1995). Tingkat kemasaman tanah $(\mathrm{pH})$ yang ideal untuk pertumbuhan selada berkisar antara 6,5-7. Pada tanah yang terlalu asam, tanaman ini tidak dapat tumbuh karena keracunan Mg dan Fe (Suprayitna, 1996). Meskipun demikian, selada masih toleran terhadap tanah-tanah yang miskin hara dan ber-pH agak masam (Rajamudin, 2004).

Pelabi merupakan kecamatan yang berada di Kabupaten Lebong Propinsi Bengkulu, dengan ketinggian $450 \mathrm{~m}$ dpl. Tanah yang berkembang di kawasan ini adalah tanah Inceptisol yang mempunyai tingkat kesuburan yang relatif rendah. Hasil analisis tanahnya menunjukkan bahwa $\mathrm{pH}$ masam berkisar 4,22 - 5,44, kandungan bahan organiknya rendah, tekstur lempung berdebu dengan kadar liat $31-53 \%$, kandungan nutrisi N, P, $\mathrm{K}$ rendah sampai sangat rendah dengan nilai KPK berkisar 18,5 - 24,27 me/100 g. Bahan organik diyakini dapat memperbaiki sifat fisik dan biologi tanah, selain itu juga memperbaiki sifat-sifat kimia tanah seperti penurunan kelarutan aluminium, meningkatkan ketersediaan hara N, P, K dalam tanah, serta meningkatkan KTK tanah melalui gugus karboksil yang aktif.

Pupuk kandang adalah salah satu pupuk organik yang sering digunakan untuk memperbaiki sifat fisik tanah dan memiliki kandungan hara yang dapat mendukung kesuburan tanah. Salah satu jenis pupuk kandang yang banyak digunakan oleh para petani adalah pupuk kandang sapi. Kotoran sapi segar mempunyai nisbah C/N 41,46, C-organik 63,44\%, $\mathrm{N} 1,53 \%$, P $0,67 \%$ dan $\mathrm{K} 0,70 \%$ (Hartati \& Widowati, 2006). Menurut Abdurachman et al., (2008) pemberian pupuk kandang sapi dengan dosis 5 ton/ha pada tanah inceptisol meningkatkan C-organik dan KTK tanah dibandingkan kontrol. Hasil penelitian Hayati (2010) menunjukkan bahwa aplikasi pupuk kandang sapi sebanyak 15 ton/ha akan memberikan berat berangkasan segar tanaman selada yang lebih baik jika diikuti penambahan pupuk anorganik.

Selain pemberian pupuk kandang, sumber nutrisi dari bahan organik lain yang juga mampu memperbaiki sifat tanah adalah abu sekam padi. Sekam padi jika dibakar akan menghasilkan abu yang mengandung silika yang tinggi dan unsur tertentu. Menurut Brooks (2009) abu sekam memiliki kandungan silika sebesar 90,23\%, Kalium oksida $\left(\mathrm{K}_{2} \mathrm{O}\right) 0,39 \%$, Alumina
$\left(\mathrm{Al}_{2} \mathrm{O}_{3}\right)$ 2,54\%, Karbon 2,23\%, Besi oksida $\left(\mathrm{Fe}_{2} \mathrm{O}_{3}\right)$ 0,21\%, Kalsium oksida $(\mathrm{CaO})$ 1,58\%, Magnesium oksida (MgO) 0,53\%. Pemberian abu sekam padi pada tanah dapat membantu aerasi tanah sehingga akan memperlancar gerakan udara dan air di dalam tanah dan sangat membantu sistem perakaran tanaman (Pancadewi, 2001). Hasil penelitian Sundari (2015) menunjukkan bahwa pemberian abu dengan dosis 3 ton/ha menghasilkan jumlah daun kedelai terbanyak pada umur 8 minggu setelah tanam (mst). Penambahan abu sekam 3,75 ton sudah menunjukkan perbedaan yang nyata terhadap tinggi tanaman kedelai (Perdanatika et al., 2017). Penelitian ini bertujuan untuk menentukan dosis pupuk kandang, dosis abu sekam padi serta interaksi dosis yang optimal untuk pertumbuhan dan hasil selada.

\section{METODE PENELITIAN}

Penelitian ini dilaksanakan pada bulan Mei 2018 sampai Juli 2018 di Medan Baru Kota Bengkulu dengan ketinggian tempat $\pm 36 \mathrm{~m}$ dpl. Penelitian ini menggunakan Rancangan Acak Lengkap (RAL) dengan dua faktor dan tiga ulangan. Faktor pertama berupa dosis pupuk kandang sapi dengan taraf, yaitu: 0 ton/ha, 15 ton/ha dan 30 ton/ha. Faktor kedua berupa dosis abu sekam padi, yaitu: 0 ton/ha, 3 ton/ha, dan 6 ton/ha. Secara keseluruhan terdapat 27 unit percobaan, setiap unit percobaan terdiri atas 3 tanaman, sehingga diperoleh 81 tanaman.

Variabel tanaman yang diamati yaitu tinggi tanaman, jumlah daun, tingkat kehijauan daun, luas daun keempat, panjang akar, bobot berangkasan segar dan kering, bobot akar segar dan kering. Selanjutnya data yang diperoleh dianalisis secara statistik dengan analisis varians (ANAVA) dengan uji $\mathrm{F}$ taraf 5\%. Jika terdapat pengaruh nyata maka akan dianalisis dengan menggunakan metode Polynomial Orthogonal taraf 5 \% (Yitnosumarto, 1990).

\section{HASIL DAN PEMBAHASAN}

Penelitian ini menggunakan media tanam tanah inceptisol yang diambil dari Kabupaten Lebong. Analisis tanah pada saat awal penelitian menunjukkan pH 4,60 (masam), KTK 24,07 cmol/kg (sedangtinggi), C 3,48 \% (tinggi), tekstur (\% pasir : \% liat : $\%$ debu $)=(41,11: 27,80: 31,09)$, dengan kandungan hara Kadar N 0,31 \% (sedang), Kadar P-Bray 11,00 $\%$ (tinggi), K 0,20 cmol/kg (rendah), Ca-dd 2,22 me/100 g (rendah), dan Mg-dd 1,11 me/100 g (sedang)

Hasil analisis varians menunjukkan bahwa tidak terdapat interaksi antara perlakuan pupuk kandang sapi dan abu sekam padi pada semua variabel pengamatan. Pupuk kandang sapi sebagai faktor tunggal memberikan pengaruh nyata pada variabel tinggi tanaman, jumlah daun, luas daun, dan bobot 
brangkasan basah, sedangkan perlakuan abu sekam padi sebagai faktor tunggal berpengaruh tidak nyata terhadap semua variabel yang diamati.

Tabel.1 Rangkuman hasil analisis varians pada perlakuan pupuk kandang sapi dan abu sekam padi terhadap variabel pertumbuhan dan hasil selada

\begin{tabular}{|c|c|c|c|c|}
\hline \multirow[b]{2}{*}{ No } & \multirow[b]{2}{*}{ Variabel Pengamatan } & \multicolumn{3}{|c|}{ F Hitung } \\
\hline & & $\begin{array}{c}\text { Pupuk Kandang } \\
\text { Sapi } \\
\end{array}$ & $\begin{array}{c}\text { Abu Sekam } \\
\text { Padi }\end{array}$ & Interaksi \\
\hline 1 & Tinggi Tanaman & $4,57^{*}$ & $1,03 \mathrm{~ns}$ & $0,3 \mathrm{~ns}$ \\
\hline 2 & Jumlah Daun & $5,23^{*}$ & 0,31 ns & 0,36 ns \\
\hline 3 & $\begin{array}{l}\text { Tingkat Kehijauan } \\
\text { Daun }\end{array}$ & $0,8 \mathrm{~ns}$ & $0,85 \mathrm{~ns}$ & 0,47 ns \\
\hline 4 & Luas Daun & $10,18^{*}$ & 0,88 ns & 0,07 ns \\
\hline 5 & Panjang Akar & 0,63 ns & $0,27^{\mathrm{ns}}$ & 0,12 ns \\
\hline 6 & $\begin{array}{l}\text { Bobot Berangkasan } \\
\text { Segar }\end{array}$ & $4,68^{*}$ & $0,07 \mathrm{~ns}$ & $0,5 \mathrm{~ns}$ \\
\hline 7 & Bobot Akar Segar & 0,33 ns & $0,31^{\text {ns }}$ & 0,3 ns \\
\hline 8 & Bobot Akar Kering & $1,51^{\text {ns }}$ & 3,34 ns & $2,17^{\text {ns }}$ \\
\hline 9 & $\begin{array}{l}\text { Bobot Berangkasan } \\
\text { Kering }\end{array}$ & 1,28 ns & 0,09 ns & 0,64 ns \\
\hline
\end{tabular}

Keterangan: ${ }^{*}=$ berpengaruh nyata pada taraf $5 \%,{ }^{\text {ns }}=$ berpengaruh tidak nyata

Pupuk kandang merupakan bahan organik yang dapat memperbaiki kesuburan dan sifat tanah. Selain itu, bahan organik mampu meningkatkan kemampuan tanah dalam mengikat lengas serta memperbaiki struktur tanah. Secara biologi, bahan organik dapat memacu pertumbuhan dan perkembangan biota dalam tanah sehingga dapat mempercepat tersedianya hara bagi tanaman. Berdasarkan hasil analisis Pangaribuan et al. (2012), bahwa bokashi pupuk kandang sapi mengandung unsur N-total sebesar $0,95 \%$, P Bray 0,18\%, K 0,58\%, dan C-organik 11,93\%. Unsur N sendiri berfungsi merangsang pertumbuhan hampir secara keseluruhan, sementara unsur P merangsang pertumbuhan akar sehingga tercipta sistem perakaran yang baik untuk menyerap hara dan air secara efisien. Unsur $\mathrm{K}$ diperlukan tanaman dalam mengaktifkan enzim-enzim yang dapat mempercepat pertumbuhan jaringan meristimatik (Setyamidjaya, 1986).

Dosis pupuk kandang sapi terhadap variabel tinggi tanaman membentuk grafik hubungan linier positif dengan pesamaan $\mathrm{y}=15,43+0,189 \mathrm{x}$ dan nilai koefisien determinasi $\mathrm{R}^{2}=0,857$. Hal ini berarti pada setiap penambahan satu satuan dosis pupuk kandang sapi akan diikuti dengan peningkatan nilai tinggi tanaman selada rata-rata sebesar 0,189.

Tinggi tanaman merupakan variabel yang erat kaitannya terhadap serapan hara dan air. Ketersediaan hara dan air yang cukup akan mendukung pertumbuhan tanaman, sedangkan kekahatan unsur hara serta cekaman air dapat menyebabkan tanaman kerdil atau tidak normal pertumbuhannya. Menurut
Abdurachman et al. (2008), umumnya inceptisol memiliki tingkat kesuburan tanah rendah, kadar bahan organik dan air yang rendah. Tinggi tanaman berkorelasi terhadap jumlah daun. Daun tanaman selada terletak pada buku-buku batang semu sehingga semakin tinggi batang selada semakin banyak juga jumlah daunnya, namun pertambahan tinggi batang akan semakin meningkat jika sudah melewati batas panen atau sudah memasuki fase generatif. Oleh karena itu, penting memperhatikan umur tanaman saat dipanen.

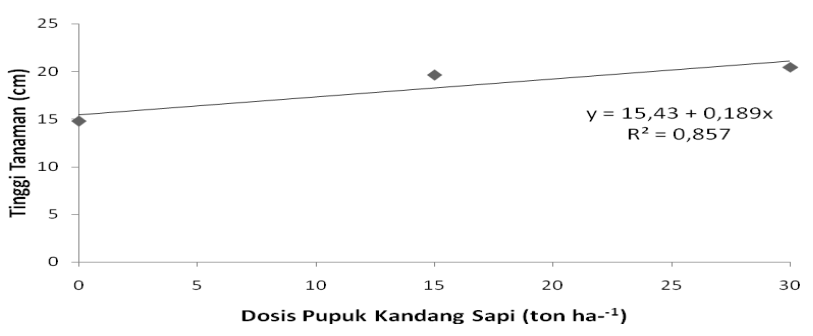

Gambar 1. Kurva hubungan dosis pupuk kandang sapi terhadap tinggi tanaman selada

Dosis pupuk kandang terhadap jumlah daun selada membentuk pola linier positif dengan persamaan $\mathrm{y}=$ $7,038+0,038 x$ dan koefisien determinasi $R^{2}=0,887$. Hal ini berarti pada setiap penambahan satu satuan dosis pupuk kandang akan diiringi dengan peningkatan nilai jumlah daun selada rata-rata sebesar 0,038.

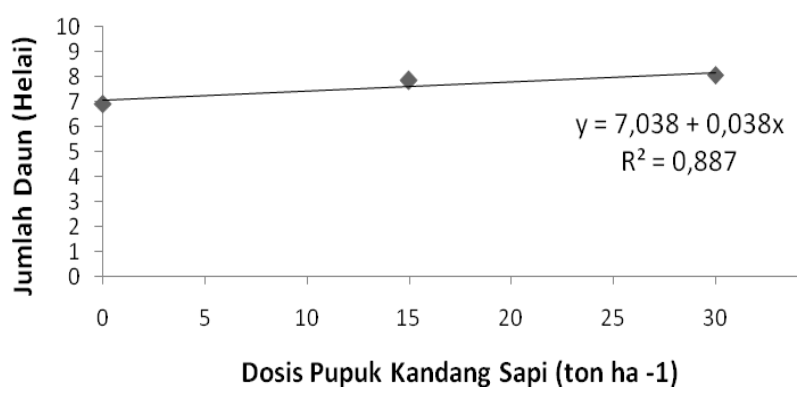

Gambar 2. Kurva hubungan dosis pupuk kandang terhadap jumlah daun selada

Peningkatan jumlah daun diduga sebagai hasil dari penyerapan hara dan air yang cukup. Dengan sistem perakaran yang dangkal maka pemberian pupuk kandang selain memperbaiki sifat-sifat tanah juga mampu memasok unsur hara yang dapat digunakan oleh tanaman walau dalam jumlah yang relatif rendah. Tanaman dengan jumlah daun yang banyak akan memperlancar proses fotosintesis. Proses fotosintesis dapat berjalan dengan baik dengan bantuan enzim yang aktif dikarenakan meningkatnya kalium dalam tanah

Dosis pupuk kandang terhadap luas daun tanaman selada membentuk pola linier positif dengan persamaan y $=61,86+0,931 \mathrm{x}$ dan koefisien determinasi 
$\mathrm{R}^{2}=0,908$. Hal ini berarti setiap penambahan satu satuan dosis pupuk kandang akan dibarengi dengan peningkatan nilai luas daun sebesar 0,931. Pertambahan nilai luas daun akan menambah keefektifan penangkapan sinar matahari secara optimal untuk proses fotosintesis yang nantinya akan menghasilkan luaran berupa fotosintat yang lebih besar sehingga akan mendukung pertumbuhan daun dan organ lainnya.

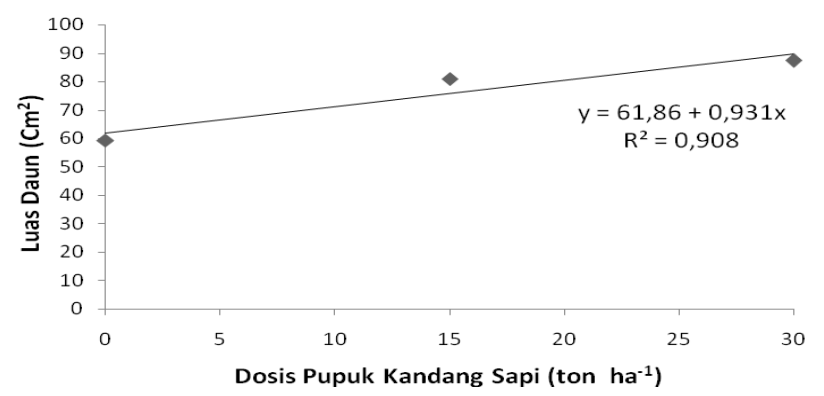

Gambar 3. Kurva hubungan dosis pupuk kandang terhadap luas daun tanaman selada

Tinggi tanaman, jumlah daun, dan luas daun mempengaruhi berat berangkasan segar tanaman. Hasil analisis varians menunjukkan bahwa dosis pupuk kandang berpengaruh nyata terhadap berat berangkasan segar tanaman selada. Dosis pupuk kandang terhadap berat brangkasan segar tanaman selada membentuk pola linier positif dengan persamaan $\mathrm{y}=$ $18,84+0,104 \mathrm{x}$ dengan koefisien determinasi $\mathrm{R}^{2}=$ 0,820 . Hal ini berarti pada setiap penambahan satu satuan dosis pupuk kandang akan diiringi dengan peningkatan berat berangkasan segar tanaman selada sebesar 0,104.

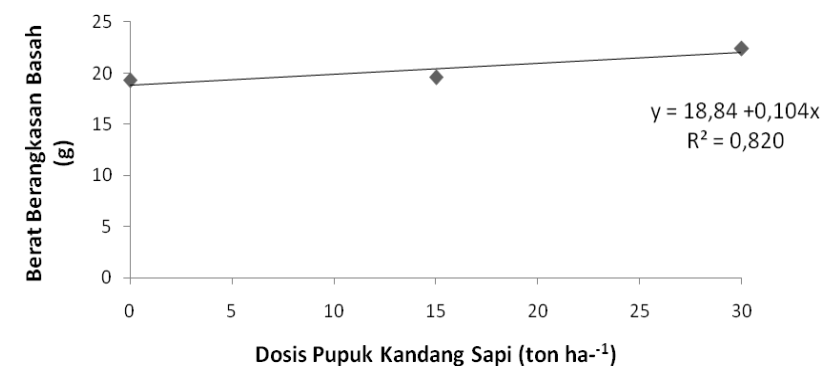

Gambar 4. Kurva hubungan dosis pupuk kandang terhadap berat berangkasan segar tanaman selada

Berat berangkasan segar merupakan hasil akumulasi dari semua organ vegetatif tanaman. Pertumbuhan tanaman yang baik akan menghasilkan bobot segar tanaman yang tinggi karena jumlah kandungan air di dalam sel tanaman (Rasada, 1996). Pupuk kandang sapi memiliki kandungan hara $\mathrm{N}$ yang relatif tinggi yakni 0,3 \% (Lingga, 1991). Unsur hara $\mathrm{N}$ yang disumbangkan mampu mendukung pertumbuhan organ-organ vegetatif seperti batang dan daun. Pemberian pupuk kandang mampu menambah kandungan hara dalam tanah sehingga akivitas metabolisme lebih aktif, akibatnya proses pemanjangan dan diferensiasi sel akan lebih baik, sejalan dengan pendapat Prawinata et al. (1994) bahwa berat basah brangkasan adalah cerminan dari komposisi hara jaringan tanaman.

Pengaruh tidak nyata secara statistik diduga akibat belum terdekomposisinya abu sekam padi di tanah, mengingat bahwa abu sekam padi yang digunakan adalah hasil pembakaran dengan suhu $105{ }^{\circ} \mathrm{C}$, sehingga abu masih memiliki tekstur kasar dengan kadar $\mathrm{C} / \mathrm{N}$ rasio masih cukup tinggi dan memerlukan waktu yang panjang untuk dapat terdekomposisi sempurna sehingga mampu memberikan pengaruh bagi tanaman. Nilai nisbah $\mathrm{C} / \mathrm{N}$ abu sekam padi yang tinggi mengakibatkan lambatnya proses dekomposisi dikarenakan tingginya kadar C-Organik abu sekam padi sehingga sulit untuk diuraikan oleh dekomposer. Proses dekomposisi yang lambat juga dipengaruhi oleh $\mathrm{pH}$ tanah yang masam, sehingga mikroorganisme pengurai yang ada pada tanah tidak mampu hidup dengan baik untuk mendekomposisi bahan organik pada tanah.

\section{KESIMPULAN}

Hasil penelitian menunjukkan bahwa tidak terdapat interaksi antara dosis pupuk kandang sapi dan abu sekam padi terhadap pertumbuhan dan hasil selada. Pengaruh pupuk kandang sapi belum menunjukkan dosis optimum bagi pertumbuhan dan hasil selada. Penambahan dosis pupuk kandang hingga 30 ton/ha mampu meningkatkan nilai tinggi tanaman, jumlah daun, luas daun, dan bobot berangkasan segar tanaman berturut-turut sebesar $0,189,0,038,0,931$, dan 0,104 . Pemberian abu sekam padi hingga dosis 6 ton/ha memberikan pengaruh yang tidak nyata pada semua variabel yang diamati.

\section{DAFTAR PUSTAKA}

Abdurachman, A., Dariah, A. \& Mulyani, A. (2008). Strategi dan teknologi pengelolaan lahan kering mendukung pengadaan pangan nasional. Jurnal Litbang Pertanian, 27(2), 4349.

Brooks, R.M. (2009). Soil stabilization with fly ash and rice husk ash. International Journal of Research and Reviews in Aplied Sciences, 1 (3),.209-217.

Harianto, E.T., Suhartini \& Rahayu, E. (1995). Sawi dan Selada, Penebar Swadaya, Jakarta.

Hartati, W \& Widowati, L.R. (2006). Pupuk Kandang. Balai Besar Litbang Sumberdaya Lahan Pertanian Badan Penelitian dan Pengembangan Pertanian, Bogor. 
Hayati, E. (2010). Pengaruh pupuk organik dan anorganik terhadap kandungan logam berat dalam tanah dan jaringan tanaman selada. $J$. Floratek, 5, $113-123$.

Lingga, P. (1991). Jenis dan kandungan hara pada beberapa kotoran ternak. Pusat Pelatihan Pertanian dan Pedesaan Swadaya (P4S) ANTANAN. Bogor.

Pancadewi, S. (2001). Uji Pemberian Abu Sekam Padi dan Pupuk Kandang Sapi Terhadap Perilaku Fisik Entisol. Jurnal Ilmu Pertanian: Mapeta, 3(9),17-24.

Pangaribuan, D.H., Yasir, M. \& Utami, N.K., (2012). Dampak bokashi kotoran ternak dalam pengurangan pemakaian pupuk anorganik pada budidaya tanaman tomat. Jurnal Agronomi Indonesia (Indonesian Journal of Agronomy), 40(3).

Perdanatika, A., Suntoro, S. \& Pardjanto, P. (2017). Respon Penambahan Abu Sekam dan Dolomit terhadap Pertumbuhan Kedelai di Tanah Alfisol. In Prosiding Seminar Nasional Fakultas Pertanian UNS 1(1):19-24.
Prawiranata, W., Harran, S. \& Tjondronegoro, P. (1994). Dasar-dasar Fisiologi Tumbuhan. Departemen Botani. Fakultas Pertanian. Institut Pertanian Bogor, Bogor.

Rajamudin, U. (2004). Pengaruh Pemberian Bahan Organik (Sampah Pasar) Terhadap Beberapa Sifat Kimia Entisol Lembah Palu. Skripsi Universitas Tadulako, Palu.

Rasada. (1996). Pengaruh Beberapa Dosis Pupuk NPK dan Mg Terhadap Pertumbuhan Tanaman Kakao Setelah Pangkasan Pada Umur Tanaman Menghasilkan. Skripsi. Fakultas Pertanian Universitas Andalas, Padang.

Rukmana, R. (2007). Bertanam Selada dan Sawi. Kanisius, Yogyakarta.

Setyamidjaja, D., (1986). Pupuk dan Pemupukan. CV. Simplex, Jakarta.

Suprayitna, I., (1996). Menanam dan Mengolah Selada Sejuta Rasa. CV. Aneka,. Solo.

Yitnosumarto, S. (1990). Percobaan : Perancangan, Analisis dan Interpretasinya. Gramedia Pustaka Utama, Jakarta. 